\title{
PSYCHIATRY AND THE LAW: AN ATTEMPT AT SYNTHESIS*
}

\author{
Raymond L. Ericksonì
}

THAT THERE EXIST certain basic conflicts between current of the assumptions underlying jurisprudence is a truism, but it sometimes requires a personal experience with a particular case to bring the contradictions into sharp focus. Some time ago, the writer, while functioning as a psychological intern in a state prison system, encountered a situation in which some of the conflicts were clearly manifested.

A relatively new inmate had expressed a desire to be considered for parole at a time that was somewhat premature for much hope of success, and during an interview, he presented the following account.

He had been charged with a sexual offense involving children, of which he was guilty, and had been committed to a mental institution for examination under the state's sex psychopath law rather than sentenced for his crime. He was found to be a sexual psychopath, and after the initial ninety-day observation, he was recommitted on an indeterminate commitment. He spent a total of eighteen months at the state hospital, undergoing psychotherapy for most of that period. When the staff felt that he could not profit from further care and treatment at the hospital, he was sent back to the court for consideration of the criminal charge that had been made against him, as was mandatory in such situations. He brought with him a recommendation from the superintendent of the hospital that stated precisely that he had received maximum benefit from psychotherapy and was "no longer a menace to the health and safety of others." The superintendent further recommended that the ex-patient be given probation and continued psychiatric treatment after his release.

The following is a direct quotation (from the court record) of part of the presiding judge's statement:

* The research necessary for this article was made possible by a grant from the John Randolph Haynes and Dora Haynes Foundation.

$\dagger$ B.A. 195x, University of Buffalo; M.A. 1953, University of California at Los Angeles. Assistant Professor of Psychology, Whittier College. Formerly Clinical Intern, Dep't of Corrections, State of California. 
We have a situation here somewhat analogous to a person who commits a crime suffering from some pathology, the pathology is cured, but that doesn't entitle him to be relieved from the penalties. In other words, this is not merely a question as to whether a person has adopted a different attitude towards the crime he has committed. If he has committed a crime sufficiently serious to come within the principles of penology, he comes within those principles, even though he has changed his attitude. You might have a chronic thief who suddenly has gotten religion after he has committed a series of serious offenses, but because he has gotten religion, is not going to steal anymore, is no reason why the penalty should be removed. We have here a particularly aggravated case. There was a degree of preparation for commission of these offenses, in other words, an anticipation of committing offenses of this kind, the fellow so prepared his pocket he didn't have any bottom to it, and so forth....

I have got to consider more than the mere matter of reformation. The administration of criminal law is not solely intended to reform the individual, and if the individual is reformed by the time he gets into court- $\mathrm{I}$ think we have to take a case of this sort where a person with his eyes open has committed serious violations of the law; I can't conscientiously grant probation... : (Emphasis added.)

The judge then proceeded to sentence the ex-patient to an indeterminate sentence of one year to life in the state penitentiary.

His decision, an outstanding example of the retributive function of justice, brings to the fore the inevitable conflict ensuing whenever there is no unifying, consistent philosophy underlying the functioning of a social institution. Such an absence of unifying principles is a salient characteristic of the administration of justice not only in the state in question, but throughout the United States. ${ }^{1}$ Here and there can be found parts of the whole that are based upon a positivist theory of justice, but coexisting with them are other aspects of the total system that are definitely classical and punitive in nature. The sex psychopath laws, with all of their very real shortcomings, are at least an attempt to deal with the problem of crime in a positivist manner. But when they must be administered within the framework of a juridical system that remains basically punitive in its orientation, logical contradictions are the inevitable result. Our system of jurisprudence is neither fish nor

\footnotetext{
${ }^{2}$ Regarding this particular conflict, Indiana, New Hampshire, and Michigan have provided that commitment as a sexual psychopath disposes of the criminal charge. IND. Ann. Stat. $\$$ 9-3409 (1956); N.H. Rev. Stat. Ann. $\$ 173: 13$ (1955); Mich. Comp. LAws $\$ 780.508$ (1948).
} 
fowl; "[we] attempt to serve a confusion of all possible ends of criminal justice by a confusion of all possible methods."2

If one were to investigate the differences of opinion regarding the proper end that the criminal law is to serve, it would be found that most could be related to the difference between two basic theoretical orientations. One approach, based upon Kant's philosophy, holds that the criminal law should mete out punishment as retribution for crime. According to this theory, justice is concerned with the "rightness" of the individual; if he behaves "badly," he has earned punishment or retribution, and the actual effect that this retribution has upon him is of only secondary consideration. The other basic interpretation of the proper end of criminal law is that it ought to serve the welfare of the state by preventing crime. The means used to accomplish this, according to the utilitarian theory, are of secondary importance. They may or may not involve punishment; but if they do, the punishment is justified only if, according to Bentham, "it prevents some greater evil," or in other words, contributes to the end of preventing crime, protecting society, and enhancing the welfare of the state. Psychiatrists, in their voluminous criticisms of the law, tend to accept the utilitarian theory as representing the proper end of criminal justice, while a significant percentage of the members of the judiciary tend to emphasize the end of retribution. It is to be the major purpose of this paper to demonstrate that these two ends are not mutually exclusive, and, more explicitly, that the goal of the utilitarian theory cannot be adequately realized unless proper recognition is given to the end set forth in the retributive theory.

The lack of agreement between members of the two professions of psychiatry $^{3}$ and the law as to what constitutes the proper end of criminal

'Gausewitz, Considerations Basic to a New Penal Code, Part II, I I Wis. L. REv. $346,542(1936)$.

"Psychiatry," unless otherwise stipulated, will be taken here to involve psychology, "the science of human behavior and experience," and to mean roughly, a scientific view of man. This obviously includes social aspects, and is by no means a "purely medical" approach. The historical fact that psychiatry developed within the framework of the medical profession seems to lead many writers to the erroneous assumption that psychiatry is "biological" and that the psychiatrist is no more competent to deal meaningfully with social factors than an opthalmologist. It should also be made clear that when we speak of "psychiatry," we are referring to a group that is in the vanguard of a movement to reform our traditional punitive system for dealing with criminals, a movement that has already accomplished much. Not all persons who advance the views herein ascribed to psychiatry are psychiatrists; likewise, not all psychiatrists adhere to these views. The latter point causes some to question the degree to which psychiatry is "scientific," while it should lead them to question the advisability of generalizing beyond one's area of competence. 
justice is at least in part a result of the differing concepts of the nature of man which are held. Simply put, the major difference is that members of the legal profession tend to picture man as a free moral agent with the capacity to choose between right and wrong acts, while most psychiatrists, by remaining true to the scientific picture of man that has been evolved during the last seventy years, conceive of man's behavior as completely subject to the influence of antecedent determining factors. ${ }^{4}$. They would, of course, admit that man has a conscious experience which he calls "making a choice"; but the choice that he will make has already been determined ${ }^{5}$ by antecedent circumstances, and his conscious experience of making a choice is merely his subjective awareness of the means whereby the influences of previous experiences and other antecedent conditions are synthesized. Man may feel that he has complete control over this synthesis of factors when making a "decision," but in actuality, he has not, for his subjective experience of control often does not include an awareness of many of the most important factors involved in the synthesis. In other words, unconscious motivation influences a great many of our decisions in a major way, and is probably involved to some extent in all of them.

It is hardly necessary to point out that these two concepts of the nature of man are incompatible. The law is based upon the assumption that free will exists. It allows for certain exceptions-for example, insane and other mentally diseased persons-but other than these exceptions, wrongdoers are held responsible for their acts because it is assumed that they have the ability to do right if they so desire. Most psychiatrists would maintain that this is not so, for acts are predetermined and the concept of "responsibility" is not scientifically meaningful." From this (and here is where the ranks of psychiatry begin to diverge more), some conclude that the use of punishment is both illogical and fruitless, either as a means of individual treatment or as a means of general deterrence, and that the only meaningful approach to criminality lies in the use of psychotherapy, which will bring about a change in the

\footnotetext{
‘Many psychiatrists would perhaps deny ascribing to such an extreme position; but in spite of the philosophically erudite proclamations to the contrary made by some to make their position more palatable to others and perhaps to themselves, most psychiatrists are deterministic in their approach.

'Which does not mean that it was foreordained (i.e., determined before the occurrence of the antecedent set of circumstances), a frequent source of confusion, for some obscure reason.

${ }^{\circ}$ Note that this is not the same as saying that it is not a useful, or perhaps even necessary, concept.
} 
(usually unconscious) factors that have influenced the person in such a way that he has committed a crime.

When one considers the extreme disparity between the "deterministic" and "free will" interpretations of man's behavior, it becomes somewhat puzzling that there has been any rapproachement whatsoever between psychiatry and the law. As one writer says:?

... we discover what we should have known all along-that genuine scientific "causal" theories render the assignment of moral "blame" to persons unnecessary and, in fact, impossible. If we take physics and its various branches seriously, we conclude, as indeed most people in our society have concluded, that we cannot blame the gods if our crops fail or if our cattle die. Similarly, if we would take psychology and its branches seriously, as very few people seem prepared to do, we might conclude that we cannot blame men for what they do. They, too, have their "reasons," but, to "understand" does not necessarily mean that one must "forgive."

The explanation for the degree of rapport that exists would seem to be that only a few psychiatrists really take psychology and its branches seriously as far as their practical relations in everyday life and the functioning of the criminal law are concerned. Even such extreme advocates of the "psychiatric position" as Franz Alexander and Gregory Zilboorg would probably hesitate to say that there is no advantage whatever in holding anyone morally responsible for anything. The majority of forensic psychiatrists, regardless of what they might proclaim as their theoretical position on the question of determinism, have behaved in their relationships with the law as if they considered the "normal" individual to be morally responsible and, therefore, accountable for his acts. Their major contention with the law has not been over whether or not it is possible to attach moral responsibility to anyone at all, but over the criteria to be used in determining who should be held responsible for his acts and who should not. In fact, some are quite insistent upon the recessity for side-stepping the whole issue and thereby ignore the fact that regardless of what they say, the functioning of psychiatry is based upon the assumption of determinism.

Bromberg and Cleckley ask: ${ }^{8}$

Is it possible for us to avoid attempts to settle the controversy over frce-will and determinism (or fore-ordination) (sic.) and still give an honest medical

\footnotetext{
${ }^{7}$ Szasz, Psychiatry, Ethics, and the Criminal Law, 58 CoLUM. L. REv. 183,192 $(1958)$.

${ }^{8}$ Bromberg \& Cleckley, The Medico-legal Dilemma-A Suggested Solution, 42 J. CriM. L., C. \& P.S. 729, 738-739 (1952).
} 
opinion about the questions we are asked in court? . . . Refusing all temptations to assume the role of arbiter in questions of man's moral obligations, (or whether or not any such obligations exist), Grasset ${ }^{9}$ confines himself to difficult enough but medically approachable problems. $\mathrm{He}$ attempts a judgment on whether or not the capability of the organism is impaired. . . . As employed by Grasset long ago, it is the (medical) expert's job to give an opinion on whether or not the particular subject is damaged or deranged to such a degree that he cannot be counted on to show ordinary functional capacity. If we attempt to include in our opinion the ultimate solution of the free-will versus determinism argument, our opinion is not likely to be of practical value. Who can say that philosophical determinism has any better claims to final proof than free-will?

These same writers make several specific suggestions for a solution to the medico-legal dilemma, among them the following: ${ }^{10}$

That psychiatrists avoid the ultimate problem of free-will and determination in their medical judgments, since the issue of mental disease and crime can be met adequately short of the ultimate philosophic and religious questions involved. To implement this orientation it is recommended that the concept of "accountability" be substituted for that of "responsibility" in the legal test for criminal responsibility. This would mean that the question given the expert witness would be in language approximately as follows: "In your opinion, was the defendant suffering from disease of the mind and if so, was it sufficient to render him unaccountable under the law for the crime charged?"

The basic problem, as perceived by these authors along with many others, is to give the psychiatrist an opportunity to testify in a meaningful fashion regarding the "accountability" (or responsibility) of the accused.

\footnotetext{
- Joseph Grasset was Professor of Ćlinical Medicine at the University of Montpellier, and in 1907 wrote a book called Demifous et Demiresponsables [The Semi-Insane and the Semi-Responsible]. In this work, he attempted to delineate three levels of responsibility for behavior (sane, insane, and semi-insane) in terms of the relationships among neurological mechanisms in the central nervous system. To the extent that the "superior psychic center" was intact and functioning, free-will was assumed to be operating and the person could behave in a voluntary, responsible manner. If the functional neural connections between the "superior psychism" and the lower "inferior psychism" were impaired or eliminated, the person was semi-insane or insane, respectively. Grasset thus considered the problem of semiresponsibility to be strictly a medical problem, since it was thought to be based upon a neurological condition: Needless to say, his concepts of "superior and inferior psychic centers" residing in specific groups of neurons and related directly to specific aspects of personality function, such as the exercise of free will, are not substantiated by present-day neurology or personality theory. (Author's footnote.)

${ }^{10} \mathrm{Id}$, at $7+1-42$.
} 
Some persons are in such a mental state that they should not be held accountable, regardless of whether or not they (or anyone else) are "really responsible" in an ultimate philosophical sense. Of course, what is being protested by these critics who wish to give the psychiatristwitness greater opportunities for offering meaningful testimony is the law's tenacious adherence to the antiquated criteria for determining legal insanity (and hence irresponsibility for crime) laid down in the M'Naghten Rules. Undoubtedly, more has been written about the M'Naghten Rules than about any other single topic relevant to the relationship between psychiatry and the law. They were attacked by some from their very inception on essentially the same grounds that they are attacked today, and they are still being defended as the best possible guide to determining criminal irresponsibility. It is unnecessary to present a thoroughgoing analysis of the M'Naghten Rules here, but a consideration of their major characteristics is in order.

The M'Naghten Rules were formulated in England in 1843 , following an attempt on the life of Prime Minister Robert Peel by one Daniel M'Naghten. Although there are several aspects to them, the essential criteria for determining legal insanity which they lay down are as follows: ${ }^{11}$

... to establish a defense on the ground of insanity, it must be clearly proved that at the time of committing the act the accused was laboring under such a defect of reason, from disease of the mind, as not to know the nature and quality of the act he was doing, or if he did know it, that he did not know he was doing what was wrong.

Even without considering the numerous difficulties that arise as soon as one attempts to apply this rule-for example, defining the meaning of the words "know," "nature," "quality," and "wrong"-one is impressed by the fact that there is but little relationship between the criteria for insanity that it sets forth and the criteria for mental illness which are utilized by contemporary psychiatrists. It is quite possible for a psychotic suffering from severe delusions and hallucinations to "pass the test," and, in fact, it has frequently happened that persons whom any competent psychiatrist would adjudge psychotic have been found to be "legally sane." Psychiatrists, at least a good many of them, have been agitating for years to get the rules changed so that they could, in court, make more meaningful statements about the psychological state of the accused person. Unider the M'Naghten Rules, they are forced

\footnotetext{
${ }^{11}$ M'Naghten's Case, 1o Cl. \& Fin. 200, 210, 8 Eng. Rep. 718, 722 (1843).
} 
to attempt a description of the accused's mental state in terms of such criteria as "knowing the difference between right and wrong"" or "knowing the quality of the act," concepts that have no meaning whatever to most psychiatrists, and that have only doubtful significance to lawyers, ${ }^{12}$ although the latter usually insist that they are meaningful, if only the psychiatrists would stop "resisting." In a consideration of this problem, Gregory Zilboorg has a hypothetical psychiatrist say: ${ }^{13}$

When they all individually and jointly [judges, lawyers, and jury], ask me whether the defendant in the dock is in my opinion insane, I must candidly state, if I am to remain true to my professional knowledge and faithful to $\mathrm{my}$ oath, first, that I do not understand the question, and second, that since I don't understand the question, I do not know whether the defendant is insane or not. I admit the situation is embarrassing and puzzling to all concerned, but it is beyond my knowledge and power to remedy or alleviate it. ... We have reached a rather disquieting parting of the ways. This is undesirable from both your - [the jurist's] point of view and mine. Your rules are unintelligible to me, and my inability to follow them is unintelligible to you.

The basic complaint of the psychiatrists is that the law, in utilizing the M'Naghten Rules, imposes upon man an abstract and artificial conceptualization of his mental functioning and its relationship to behavior. If a psychiatrist is to be "true to his professional knowledge and faithful to his oath," he cannot accept this distortion of reality, and must protest. The argument used by the defenders of the M'Naghten Rules which points out that the law does not presume to define insanity, but only to establish absence of criminal responsibility, offers the psychiatrist little satisfaction; for when he considers that the manner in which irresponsibility is established usually involves obtaining expert testimony from someone regarding the mental state of the accused, he cannot help but feel that he should be able to give such testimony without abandoning his professional knowledge.

The strong criticisms made of the M'Naghten Rules have led to

12 The different interpretations given to the various parts of the formula are indicative that it is by no means as simple and straight-forward, even to lawyers, as they like to imagine. For instance, some states interpret the word "wrong" to mean "morally wrong," while others take it to mean "against the law," a difference in meaning that is of no little importance when attempting to determine whether or not a person "knew his act was "wrong." "

13 Zilboorg, Mind, MEdicine, AND MAN 272, 274 (1943). 
numerous variations in the way in which they are utilized, but in considering their present status in the United States, we can still say that: ${ }^{14}$

In all jurisdictions, except the District of Columbia and New Hampshire, the McNaghten Rules have been adopted and are still followed, though a a number of States have introduced modifications and qualifications of them.

The most common modification has been the addition of the "capacity to conform" aspect (more commonly and less desirably called the "irresistible impulse" test). This additional criterion makes it possible for a person to be declared criminally irresponsible if it can be satisfactorily, demonstrated that even though he may have known the nature and quality of his act and known that it was wrong, he was unable, through any act of volition, to behave other than he did. ${ }^{15}$ It is diffcult to generalize, since there is so much variation both in the strictness of the interpretation put on the M'Naghten Rules by different judges in charging their juries, and in the willingness of juries to adhere to a particular interpretation, but it appears that the right-and-wrong test, as the M'Naghten Rules are sometimes called, is the sole test of responsibility in approximately thirty of our states, while it is the primary test, supplemented only by the "capacity to conform" test in all the remaining jurisdictions except the District of Columbia and New Hampshire.

New Hainpshire has enjoyed the distinction of having had, since I869, a rule essentially the same as that which created such interest when, in 1954, the Court of Appeals for the District of Columbia overthrew the M'Naghten Rules, stating: ${ }^{16}$

The rule we now hold must be applied on the retrial of this case and in future cases is not unlike that followed by the New Hampshire court since 1870 . It is simply that an accused is not criminally responsible if his unlawful act was the product of mental disease or mental defect....

The implications of this brief statement require some thought in order that their full significance be realized. It has been hailed as a godsend by those who have long advocated a more realistic evaluation of criminal responsibility, and condemned as an opening wedge in the eventual breakdown of criminal law by some of the more traditionallyminded. It has produced a flurry of publications pro and con, and in spite of the oft-indicated fact that a similar rule has been in operation

\footnotetext{
"Donnelly, Establishment of Criminal Responsibility, 33 ConN. B.J. 137 (1959).

${ }^{15}$ A state of affairs which, if we take psychology "seriously," applies to all behavior.

${ }^{16}$ Durham v. United States, 214 F.2d 862 (D.C. Cir. 1954).
} 
in New Hampshire since 1869 , its inception has resulted in some new and serious thinking about the existing rules governing legal insanity.

The major theoretical change brought about by the Durham Rule (or the "product rule," as it is sometimes called) is that the problem of insanity is changed from a matter of law to a matter of fact. The perhaps more important practical difference is that under it, the expert medical witness can testify about the mental condition of the accused without being forced to describe that condition in terms of mental states that have existence only in the conceptual schemes of lawyers. This basic change is the reason why the Durham Rule has been described by some psychiatrists as a revolutionary forward step.

The fear that is expressed in most of the objections ${ }^{17}$ raised to the Durham Rule is that it leaves things "wide open"-that it makes it much too easy for an accused person to be found criminally irresponsible, and that the efficacy of the law is thereby reduced. This basic reaction is expressed in various ways, including the fear that "due process" is being violated by allowing psychiatrists actually to decide who is mentally ill and who is not, ${ }^{18}$ and consternation that anybody who has committed a crime may be pronounced not responsible, ${ }^{10}$ provided that the terms "product" and "mental disease" are given liberal enough interpretations. The latter fear has a specific manifestation in the apprehension felt by many that the so-called psychopath, ${ }^{20}$ that perplexing and ubiquitous character so common among criminals, will be found to be irresponsible under the Durham Rule. The now-famous Leach case, in which an armed robber was diagnosed by seven psychiatrists as a "sociopathic personality with dyssocial outlook" (a more up-to-date and complicated term for psychopath) and adjudged under the Durham Rule to be "not guilty by reason of insanity" demonstrated that this fear is not without grounds. Leach was sent to St. Elizabeth's Hospital and within a few months petitioned for his release on a habeas corpus, claiming that he was of sound mind and therefore could not be held. The District Court ordered him released, but the Circuit Court

${ }^{12}$ See Cavanagh, The Responsibility of the Mentally. Ill for Criminal Offenses, 4 Catholic Law. 317, 368 (1958); Davidson, Criminal Responsibility: The Quest for a Formula, in Hoch \& ZUBiN (eds.), PsYchiatry AND the LAW 6I (1955); Wertham, Psychoauthoritarianism and the Lasw, 22 U. CHI. L. REv. 336 (1955).

${ }^{18}$ Cavanagh, supra note 17 , at 320 .

${ }^{10}$ Davidson, supra note 17 , at 63 .

${ }^{20}$ The psychopath is not psychotic and usually not even neurotic, but is considered by many psychiatrists to be mentally ill. See Cleckiy, The Mask of Sanity (1950). 
reversed the decision ${ }^{21}$ and ordered him retained at the mental institution, on the grounds that persons who have been found "not guilty by reason of insanity" are in a different category than persons who may have similar mental conditions, but have committed no crime. The former, according to the court, must meet more stringent criteria to obtain release once they are committed. ${ }^{22}$

It must be granted that this is a rather puzzling situation. A man whose mental state is such that he would be released had he not committed a crime is being held in a mental institution, probably indefinitely (since there is little hope for any change in his condition), and the state was forced to this action because otherwise it would have been necessary to release completely within a few months a man who had committed a serious crime. It is not surprising that many view the "step forward" made by the Durham Rule with some alarm and wonder what, exactly, lies ahead in the "forward" direction. To quote two lawyers who have had first-hand experience with some of the problems that have developed under the Durham Rule:

The Durham Rule has now had four and one-half years to prove itself workable, and has brought only chaotic uncertainty to lawyers, judges, and jurors. ${ }^{23}$

The new rule is vague and lacking in criteria understandable by an average jury, and difficult to apply. If the ultimate objective is a non-punitive system with mental hospitals and psychiatrists substituted for prisons and penologists, it is properly a problem for Congress, both legally and in a budgetary sense. ${ }^{24}$

It would seem that in spite of the fact that it is considered to be a more rational, realistic, and scientifically respectable method of determining criminal responsibility than the M'Naghten Rules ever were, the Durham Rule has been no outstanding success as an improvement in our system of justice. The fears of the critics that it would allow "anyone" to be found "not guilty by reason of insanity" seem to have been shown to have considerable foundation by a situation in which a man found not guilty by reason of insanity cannot be legitimately retained in

\footnotetext{
${ }^{21}$ See Overholser v. Leach, 257 F.2d 667, 670 (D.C. Cir. 1958).

32 For an interesting discussion of some of the complications ensuing from the Leach case, see Gasch, Prosecution Problems Under the Durham Rule, 5 CaTHOLIC LaW. 5 (1959).

${ }^{23}$ McGee, Defense Problems Under the Durham Rule, 5 CatHolic Law. 35, 43 (1959).

${ }^{24}$ Gasch, supra note 22, at 8I.
} 
a mental institution until a ruling has been passed which, in effect, makes, a special case of him and others in his category. It might seem difficult to continue to maintain that the Durham Rule really is a more rational, realistic, and scientifically respectable method of determining criminal responsibility. However, it is the contention of the writer that it is precisely because the new rule is all of these things that it cannot possibly work to improve our system of criminal law, for in order for the law to be effective, it must ignore certain aspects of reality, not the least among which is the reality of determinism in human behavior.

What is it that has really taken place, then, with the utilization of the Durham Rule? The essential point is that psychiatrists have been enabled to bring reality into the process of ascribing criminal responsibility-the law has been forced to "take psychology a little more seriously." Of course Leach was not criminally responsible! Neither is any other "sociopathic personality with dyssocial outlook," nor any exhibitionist suffering from a neurotic character disorder, nor, if you will, any human being who commits a crime! Not, that is, if you accept a scientific interpretation of human behavior. The real question to be asked then, is not who is responsible, for that is all too obvious, but who should be held responsible. The answer to the latter question is an answer that cannot be arrived at "scientifically," but can only be obtained through a careful evaluation of the ends of criminal justice, and an equally careful determination of the means that are requisite to obtaining these desired ends. Before taking up these major considerations, let us, in support of the contention that an effective system of jurisprudence does not necessarily depend upon a rejection of the "false" and a whole-hearted acceptance of that which is "true," offer the following observations made by members of the legal profession. Mr. Justice Holmes once wrote to Harold Laski: ${ }^{25}$

If I were having a philosophical talk with a man I was going to have hanged (or electrocuted) I should say, I don't doubt that your act was inevitable for you but to make it more avoidable by others we propose to sacrifice you to the common good. You may regard yourself as a soldier dying for your country if you like. But the law must keep its promises.

For the common good, Holmes was willing to assume and act as though the man were responsible, even though he knew that his act was inevitable for him.

\footnotetext{
${ }^{25}$ i Holmes-Laski LetTers 806 (Howe ed. 1953).
} 
Mr. Justice Holmes is not alone in his "cynicism." Mr. Justice Jackson expressed a similar if perhaps slightly less disturbing attitude when he said: ${ }^{26}$

How far one by an exercise of free will may determine his general destiny or his course in a particular matter and how far he is the toy of circumstance has been debated through the ages by theologians, philosophers, and scientists. Whatever doubts they have entertained as to the matter, the practical business of government and administration of the law is obliged to proceed on more or less rough and ready judgments based on the assumption that mature and rational persons are in control of their own conduct.

In other words, while it may be quite possible that there is no such thing as free will, it is absolutely necessary for us to assume that free will exists in order for government and the law to function effectively.

It remains, however, for Thurman Arnold to clarify more definitively the proper relationship between science and jurisprudence, at least as he perceives it. To quote Warren P. Hill::27

Arnold did not believe that greater knowledge of social and psychological reality by the mass of the governed would necessarily lead to a better world. On the contrary, social stability depends on the preservation of man's ignorance and false view of himself-his capacity to ignore the unconscious and unacknowledged parts of his personality, which play an unrecognized role in his actions.

His basic ideas might be expressed thus: Our behavior as social and political animals is actually determined largely by irrational impulses which, though they enable us to satisfy physiological needs, do not satisfy our compelling desire to make a rational and moral order out of a chaotic world. Our self-esteem prevents us from accepting the truth that our psychological endowment precludes free and deliberate choice between good and evil. Hence we build elaborate structures of rationalization that we call legal and economic thinking. These structures are our ideals, our "folklore." Of course, the "creeds" of our various institutions are not considered by their members as mythology, but, on the contrary, as "sound thinking," as truth, as natural law, as a body of inevitable principles. Because there is no correspondence between the ideal constructions we project and the actual practices that go on in the world, we create legal rituals and popular symbols which keep us unconscious of the discrepancy between illusion and reality, and facilitate a rough adjustment to an imperfect world. And while these

\footnotetext{
${ }^{20}$ See Gregg Cartage \& Storage Co. v. United States, 316 U.S. 74, 79-80 (1942).

${ }^{97}$ Hill, The Psychological Realism of Thurman Arnold, 22 U. CH1. L. REv. 377, 379 (1955).
} 
"little pictures" of the world, in the form of ideas and ideals-neat, tidy, trim, but simply not true-which we interpose between ourselves and the real world often hinder the solution of practical human problems (like feeding the unemployed during a depression), we need them for our morale and consolation, and our institutions would lose vitality without them. Any event which disturbs the people's belief in a "logical heaven where Reason is enthroned"28 must be attributed by them to some "devil" such as "politics" or "human nature." The union of law and the social sciences is impossible because it would tend to undermine popular faith in legal order and certainty. The "Law" cannot be made scientific but to remain effective must only keep abreast of popular attitudes .... Such ideas pervade Arnold's view of the function of criminal courts and the "creed" of law enforcement. Trials, both criminal and civil, are purely ceremonial in function and are hardly a sensible manner of setthing disputes. The true function of courts is not fact-finding but the dramatization of the ideals behind government.

And finally, from Arnold himself: ${ }^{29}$

Functionally the primary purpose of the science of the law is to be a sounding board of both the prevalent hopes and the prevalent worries of those who believe in a government of law and not of men, to reconcile these hopes and worries somewhere in the mists of scholarship and learning, and never to admit that this is what it is doing.... However, as we will attempt to show later, the pragmatic utility of a purely objective point of view is very limited. It is useful for the purpose of finding out how institutions work. It may form the basis of a technique of therapeutics. But to expect that it will take the place of faiths and ceremonies, even for those who on occasion may avail themselves of it, is to misunderstand the way of man in society.

A realistic appraisal of the nature of man and his relationship to his society necessitates accepting that in order for man to live in a relatively harmonious state, it is mandatory that he entertain certain beliefs about himself and his institutions that are not scientifically demonstrable. A more effective system of criminal law cannot be based upon a philosophy that ignores this, nor can it ignore the fact that one of its major functions is the control of the noncriminal majority in the population. If the sole function of the criminal law were the future deterrence of individuals who have already committed criminal acts and have fallen into the hands of the law, the difficulties involved in prescribing the optimum methods to be utilized would be greatly reduced. Such,

\footnotetext{
${ }^{38}$ Arnold, Apologia for Jurisprudence, 44 YALE L.J. 729, 730 (1935).

${ }^{20}$ Id. at 729,753 .
} 
unfortunately, is not the case. Even if it is agreed that the proper end of the criminal law is the utilitarian function of preventing crime, it would appear that one of the factors necessary for accomplishing this is the ascription of personal moral responsibility for our actions, involving the threat of punishment for each and every one of us should we behave in an unacceptable way.

In order to make this clear, it is necessary at this point to offer and support three propositions. The first is that anticipated punishment is effective as a deterrent; the second is the above-mentioned point that an effective criminal law can not be concerned solely with the "criminal"; and the third is that, while it may be true that there is no such thing as free will and all behavior is determined by antecedent conditions, the fact that society holds an individual responsible for his actions can influence him toward desirable behavior.

Relevant to the first point, it must be indicated that there seems to exist today an extremely widespread misconception to the effect that psychologists have demonstrated that punishment is utterly ineffective as a means of preventing undesired behavior; and since it is also very apt to produce aggression, hostility, or some other undesirable emotional state in the organism that is punished, it should never be used as a means of controlling behavior. Critics of our punitive system of criminal law are quick to point out that there is support for this contention in the fact that even though we punish criminals severely, they continue to commit crimes. An example that is frequently cited is that of pickpockets practicing their craft in the crowds that gathered to watch the hanging of apprehended pickpockets in early nineteenthcentury England. How valid are these arguments? The truth of the matter is that no psychologist has ever shown that punishment is absolutely ineffective as a means of controlling behavior. What has been demonstrated is that punishment is usually less effective and contributes less to the well-being of the organism than other means of control that involve positive reinforcement, so that positive reinforcement is preferable whenever it is possible to implement it. But this is not to say that punishment is without effect; and, it should be noted, neither is it to say that punishment may not sometimes be preferable as a means of control, even when other more "positive" means are available, since the utilization of these other nonpunitive means may involve prohibitive costs or carry with it other undesirable concom- 
mitants. It is only when the optimum immediate well-being of the individual is our primary concern that we are justified in maintaining that we should never use punishment when some nonpunitive means. can be implemented.

The argument that severe punishment contributes absolutely nothing to the prevention of crimes is fallacious. Variables of crucial importance that are usually overlooked in arguments supporting this proposition are the degree of certainty of apprehension and the strength of the need that is served by the criminal act in each case. If a man is relatively certain that he will not be caught, no threatened punishment, regardless of its severity, will be apt to have much deterring effect by itself. Similarly, if a person is very strongly motivated to commit a crime, the deterring effect of a given punishment will be much smaller. A father with hungry children is not as apt to be affected by the punishment that accompanies stealing a loaf of bread as is a father whose children are well fed. The fact that extremely strong motivation may significantly reduce the deterring effect of an anticipated punishment is, of course, one of the reasons why many individuals have committed murder or sex crimes, regardless of the severity of the punishment that they knew awaited them if they were caught. Obviously, the anticipated punishment did not deter them; but there is a great error involved in assuming that because it did not deter these particular individuals, anticipation of severe punishment had no influence at all on human conduct in that particular social group. For every rapist whose particular constellation of personality characteristics is such that he is strongly enough motivated to attack a woman in spite of the extreme punișhment attached to the crime, there may be hundreds of individuals who have similar psychological needs, but whose motivations are not intense enough to negate the effect of the anticipated punishment.

It is ridiculous, then, to assume that because some individuals commit crimes in spite of the threat of strong punitive action against them, punishment does nothing to deter crime. Those who agitate for the abolition of punishment of criminal offenders frequently are on very shaky ground, for while they can present ample evidence that a great deal of crime has been committed in situations where a punitive approach has been taken toward its control, they cannot produce any evidence whatsoever that bears on the question of what the crime rate would have been had a nonpunitive approach been taken under the same economic 
and social circumstances. Only half the requirements of Mill's Method of Difference for establishing causality have been fulfilled, which seems hardly adequate to permit the generalizations that are often made.

Another variable that is often considered to be relevant to the effectiveness of punishment as a deterrent is the degree to which the crime in question is a result of rational calculation rather than an emotionally-based, impulsive act. The point is frequently made that while kidnaping, a calculated type of crime, may have been virtually eliminated by making it a capital offense, capital punishment for murder has little deterring effect, since the majority of murders are committed by persons who are in an emotionally-aroused state in which rational calculation of consequences is at a-minimum. Even allowing for the relevance of other factors in this instance (such as the increased probability of detection by the FBI once kidnaping was made a federal offense), it does seem reasonable to assume that anticipated punishment is apt to produce a maximum of deterring effect on acts that involve a maximum of rational calculation, and a lesser effect on acts that are more impulsive in nature. However, it is again an error to assume that because kidnaping has almost disappeared and murder is still relatively common, severe puinishment for murder does little, if anything, to deter persons from' committing murder ${ }^{30}$ Before such an inference could be drawn, it would be necessary to have some evidence that circumstances exerting pressures toward kidnaping and murder are somewhere near equally common in our society. This seems hardly a reasonable assumption, and there certainly is no evidence for it. To make the point in a slightly different way, before we could say that anticipation of strong punishment has little, if any inhibiting effect on the commission of those crimes that are essentially a result of violent emotional arousal, we would need evidence bearing on their frequency in social atmospheres exhibiting socioeconomic and ideological characteristics similar to those of our own society, but in which no severe punishment of any kind is attached to such crimes. Meaningful evidence of this nature is nonexistent.

${ }^{80}$ Statistics demonstrating that states that retain capital punishment have as high an incidence of murder as those that have abolished it prove very little about the effectiveness of severe punishment as a deterrent. For one thing, other variables, such as the relative certainty of conviction are not controlled; and for another, it is not at all clear whether death is universally perceived as much more punishing than life imprisonment. The inability to accept emotionally the possibility of death actually occurring to one's self until it is immediately imminent may actually detract from the effieacy of the death sentence as a severe punishment. 
It seems psychologically naïve to assume that anticipated punishment can only be effective as a deterrent if the individual in question is consciously areare of the consequences at the crucial moment of committing or not committing his act. It implies that our decisions are influenced only by those factors that enter into the conscious experience of decision-making, an implication that is strongly refuted by some of the basic tenets of dynamic psychology. It is a strange paradox that some of the most active exponents of a dynamic approach to human personality denounce punishment as an ineffective deterrent on the grounds that anticipation of the consequences of his act is seldom part of a criminal's consciousness at the time of committing a crime, particularly if it is an "impulsive" type of crime. Obviously, there are many individuals whose personalities are so constituted that under given sets of circumstances, they commit murder. But because they were not consciously thinking of the electric chair or life imprisonment just at the particular moment of committing the act does not mean that their behavior was totally unaffected by the fact that they had learned at some previous time what the eventual result would be should they kill another human being, even though the effect was not great enough to prevent the crime from occurring. Under a different, slightly less provoking set of external circumstances, they might have been deterred. Or another person with a slightly different pattern of personality characteristics might have been deterred under the given set of circumstances.

Although it does not always prevent a crime from being committed, anticipation of punishment does have a deterring effect. Any given act is a net result of a complex, dynamic interrelationship of innumerable psychic factors, by no means all of which are accessable to the consciousness of the individual, even at any time. There is no more reason for insisting that an individual must be conscious of a threatened punishment just at a particular moment in order for it to affect his overt behavior at that moment than in insisting that a man must be "thinking about" feelings of sexual inadequacy in order for them to be a relevant factor in the motivation of such behavior as robbing a liquor store or indulging in exhibitionism. The obvious fact that anticipated punishment is not always successful in deterring some persons from expressing antisocial impulses under certain conditions by no means indicates that it has no inhibiting effect upon the expression of such impulses by 
scores of other individuals who do not commit criminal acts, but who might, were the threat of punishment not present.

Apropos of this and the second proposition offered above-i.e., that one of the proper functions of the criminal law is the control of antisocial impulses and tendencies in the law-abiding, noncriminal members of society-Ranyard West has the following comments: ${ }^{31}$

It is in the realm of fundamental social attitudes that unconscious and conscious motivation may be most at variance. We may, if we wish to retain the term, 32 call a man's "real will" that "will" which determines his conduct. But in so doing we must never forget how conduct often turns upon a hair, and that the mass of man's "will" may be shot into the opposite side of the scales by the sudden lighting up of a new apprehension or a new emotion. The division of man's mind into conscious and unconscious is, throughout, a pointer to the inconsistency, the instability, and the disharmony of that human "will" which determines our conduct and upon which our civilization has been built. To this fact we have to give full recognition in building our theory of law.

.... A balance must be set between man's social and his self-assertive impulses. Someone must set that balance with the clear aim of expressing and securing to the fullest degree possible man's physical, mental, and spiritual needs.

Many an ideology will come with us as far as this. The aim of democratic law is that men shall set this balance for themselves. But not within the prospect of a long future will men be capable of holding the balance of their own (individual) emotional life. Because of the fact and the manifestations of aggressive impulses, others must execute for us the wishes of our social selves-which we hold to be our major selves-in defiance of our periodic outbursts of selfish and self-assertive impulses. Democratic law provides us with the means to this end.

The prime operative duty of the law thus becomes the control of human aggressiveness. It is upon the fact of the potential criminal in every man that we may give to law its psychological grounding. All the fine regulations of our business relationships, our contract and municipal law, all our national law of today and our international law of tomorrow are and will be built up upon that primary fact that mankind cannot control his own aggressive acquisitiveness unaided. Human aggressive acquisitiveness has been wrongly attributed to a lack of conscientious morality in many men. We now know that some of man's worst social behavior is compatible with the highest devotion to

\footnotetext{
${ }^{32}$ West, $A$ Psychological Theory of Law, in SAYRE (ED.), INTERPRETATIONS OF Modern Legal Philosophies 767, 775, 784-86 (1947).

32 From Hegel.
} 
moral standards; indeed-very few men are able to escape from their devotion to whatever standards their consciences have acquired. The prime fact about antisocial aggressiveness is its universal potential. The prime cause of that aggressiveness is the inescapable general thwarting of selfish impulse where it conflicts with social impulse. [I] $\mathrm{t}$ is hardly necessary to say that the psychological theory of law here propounded accepts the criterion of "positive" law, that it shall carry a sanction. Nay, more, we feel that in the psychology of unconscious motivation we have the clue to the utter failure, as law, of any "law" which does not carry a sanction, and in particular of "International Law" as it is at present constituted. . . . Law pursues and corrects aggressive impulses. Upon the whole it will be found possible to separate those impulses very largely from their temporary possessors, once we really try to do so. Most men do evil things: few men wish to do them once their evil passions are removed and when the prejudices which gave rise to those passions are allayed or explained. To those few whose antisocial conduct cannot be separated from their major selves must be applied the standard of a "minimum altruism, the plain man's plain duty." They must suffer accordingly. But they will know, and we sball know, why they suffer; that their departure from rectitude is a matter of degree, a disturbance of balance in their emotional development, perhaps to be corrected by psychoanalysis, certainly to be dealt with kindly, though always with the full firmness of a society that knows its requirements and its criteria of adequate social service.

It seems probable that many of the differences existing between those who "disavow the basic premises about the penal law, viewing the condemnatory-punitive aspect of criminal conviction as unjust and irrational, ${ }^{333}$ and those who cling to a more traditional viewpoint may be rooted in the fact that the former are less cognizant of that function of criminal law which West considers here. If we could be concerned only with the needs of persons who have broken the law and whom we wish to rehabilitate (or deter from further crime in any other way), we would be faced with a much less complex problem. However, since the proper function of the criminal law includes the effective deterrence of that large percentage of the population that does not commit criminal acts but has the potential for so doing, we must evaluate any existing aspect of or proposed change in the law in light of the effect that it has upon this function as well as its effects upon individuals who have been charged with a crime. Wechsler says: ${ }^{34}$

\footnotetext{
${ }^{33}$ Wechsler, The Criteria of Criminal Responsibility, 22 U. CHI. L. REV. 367, 375 (1955).

${ }^{34} I d$. at 374 . (Emphasis added.)
} 
The purpose of the penal law is to express a formal social condemnation of forbidden conduct, buttressed by sanctions calculated to prevent it $\rightarrow$ not alone by incapacitating and so far as possible correcting the offending individual, but also by their impact on the general imagination, i.e., through the medium of general deterrence. Considerations of equality and of effectiveness conspire to demand that sanctions which are threatened generally be applied with generality upon conviction-not that the sentence disregard differences in circumstances or in individuals, but that the sentence be imposed within the framework of such formal condemnation and conviction. Responsibility' criteria define a broad exception. The theory of the exception is that it is futile thus to threaten and condemn persons who through no fault of their own are wholly beyond the range of influence of threatened sanctions of this kind. So long as there is any chance that the preventive influence may operate, it is essential to maintain the threat. If it is not maintained, the influence of the entire system is diminished upon those who have the requisite capacity, albeit that they sometimes may offend.

On this analysis, the category of the irresponsible must be defined in extreme terms: The problem is to differentiate between the wholly nondeterrable and persons who are more or less susceptible to influence by law. The category must. be so extreme that to the ordinary man, burdened by passion and beset by large temptations, the exculpation of the irresponsible bespeaks no weakness of the law. He does not identify himself and them: they are a world apart. ... Beyond such extreme incapacities however, the exception cannot go. This, to be sure, is not poetic justice. It is public justice, which in the interest of the common good prescribes a standard all must subscribe to who can, those whose nature or nurture leads them to conform with difficulty no less than those who find compliance easy.

It becomes apparent that a change which, considered superficially, appears to be in the direction of increased rationality and scientific objectivity because it allows psychiatrists to give meaningful testimony regarding an accused's mental state may actually be considered an irrational alteration in the law in that it may very well reduce rather than increase the law's effectiveness by making the responsibility criteria "realistic" thereby reducing the deterring effect of the law.

In considering the third and last proposition set forth above, let us assume, for argument's sake, that determinism exists and that free will is only imaginary, in spite of the strong conviction to the contrary held by a majority of people who, because of the vividness of their subjective experiences of making choices and their psychological needs to ascribe moral responsibility to others as well as to themselves, cling 
to a belief in the existence of free will as a last vestige of human dignity in a mechanistic, impersonal universe in which rhyme and reason appear less and less in evidence. Assume determinism to exist. What bearing does this have on any meaningful effort to erect an effective system of criminal law? It would appear, at least in so far as man is now constituted, that the success of any conceivable system of criminal law still depends upon the ascription of individual moral responsibility to human beings. Whether they are "really" responsible, whether they actually do have a free moral choice to do good or evil, is a metaphysical question, and one which is not really relevant; for unless the law proceeds upon the assumption that men are free moral agents who are responsible for their behavior, it cannot be effective as a means of controlling human conduct. To argue, as psychiatrists and other social scientists are often wont to do, that the differentiation between "sane" persons who are held responsible for their conduct, and the deranged who are not, is being made by the courts on the basis of criteria that are outdated and scientifically untenable is to quibble over details. The whole concept of man that is the basis of our law is outdated and scientifically quite untenable! The M'Naghten Rules are singled out for attention simply because they come to the fore in highly specific situations where law and science dramatically clash, embodied in lawyer and psychiatrist. If the law were really to attempt to be "scientific" in its approach, numerous undesirable results would obtain. Arnold mentions a serious one when he says: ${ }^{35}$

From any objective point of view the escape of the law from reality constitutes not its weakness but greatest strength. ... If judicial institutions become too 'sincere,' too self-analytical, they suffer the fate of ineffectiveness which is the lot of all self-analytical people. . . . They lack that sincere fanaticism out of which great government forces are welded.

Once it is clear that we are dealing with an institution that is, by necessity, grounded in an unrealistic conceptualization of human characteristics, it seems rather picayune to argue that decisions defining the line of demarcation between criminal responsibility and irresponsibility must be based upon the more up-to-date and scientific knowledge that is available to us today from the disciplines of psychiatry and psychology. Such decisions, if properly made, must ultimately rest only upon criteria that result from a serious consideration of what the effects upon

\footnotetext{
${ }^{85}$ ARNOLd, The SYMBOLS OF GOVERnMENT 44 (1935).
} 
the law's efficacy will be, should the line of demarcation be drawn in one place rather than another. Pseudo scientific rationalizations for placing it here rather than there may be necessary, for ours is an age that worships pseudo science as faithfully as it does science, but fortunately there has never been a dearth of requisite ability for this task among members of the judiciary.

However, if this form of utilitarianism is to be our approach, what role should psychiatry and the scientific conceptualization of human behavior play in an effective criminal law? Shall we simply turn our backs on scientific knowledge, ignore reality, deny the existence of what are well-established factors in the causation of criminal behavior? Such an inference would be quite at variance with the major contention of this paper, which is that we should effectively utilize what scientific knowledge we have to gain the ends we desire, but that we cannot, in so doing, ignore the relevance and importance of certain.realities of human interaction, such as the obvious but often-neglected fact that a great deal of man's social behavior is determined by what others expect of him and what he believes to be true, rather than by what actually is true. There is much that psychiatry has to offer that can be of extreme value in reducing the crime rate, but the elimination of punitive elements in the criminal law and the widespread dissemination of the notion that there is no such thing as moral responsibility or "bad" behavior, but only "illness," are not, in the writer's estimation, part of this valuable offering.

One of the most disturbing qualities of social science (which it shares with physical science) is its delusion that it is utterly divorced from the area of value judgments and ethical considerations. In the minds of many of its protagonists, social science is conceived as being concerned only with the determination of "truth"; with description, not prescription; with the gradual development, through the utilization of the scientific method, of a substantial body of laws describing the relationship between independent and dependent variables. The determination of the ends for which these scientific truths are to be utilized is seldom, if ever, considered to be a scientific question, since it is one that can only be answered by taking into account moral and ethical considerations, which are not accepted as being within the realm of the social scientist. Such an attitude can be a most convenient rationalization for denying any personal responsibility for one's influences on 
society. That a particular widely-held belief or attitude integral to the effective functioning of an institution may be dissipated or destroyed by a scientific discovery is not felt by the social scientist to be any of his concern; his conscience is clear, for he is interested only in "truth," and who dares level disapprobation at one pursuing this lofty ideal? The fact of the matter is, however, that whether they are willing to accept the responsibility or not, social scientists do have definite influences upon matters of ethical concern. And what is more, they frequently exert a deliberate influence, escaping to their fortress of scientific "objectivity" only when they are challenged.

A succinct description of this attribute of scientists in general is made in the following comment about psychology by Robert Redmount: ${ }^{36}$

The sentient view that psychology takes of science is, in itself, a presentment of values. It stands as an affirmative condition of the psychological contribution that it expresses no personal bias toward its subject. The reality, criticism holds, is that this psychologist's view is delusive. It is merely a screen through which psychology manipulates a human subject matter without accepting the consequences of its activity. It can see the social implications of some of its findings-in fact, it may have intended them-but it denies that the structure of many of its efforts is value-oriented. It too often refuses the responsibility of relating the psychological contribution to the larger texture of social knowledge and experience into which it sometimes deliberately weaves itself.

The relevance to the point under consideration seems clear. It is not necessary to deny the existence or the importance of psychological contributions, but only to feel the responsibility for relating them in the most effective way to the "larger texture of social knowledge and experience." Hence, if we are effectively to utilize psychology's contributions to improve the effectiveness of our criminal law, we must not only determine what the relevant concepts are, but also ascertain in what ways they can be most advantageously incorporated.

Perhaps psychology's most important single contribution has been the demonstration of the existence of unconscious motivation and its relationship to criminal acts. It would appear that the area in which this concept can most effectively be applied is that involving the rehabilitation of some individuals, via psychotherapy, who have been

\footnotetext{
${ }^{B 0}$ Redmount, A Pantoscopic Viesw of Law and Psychology, io J. Legal Ed. 436, 440 (1 $\left.95^{8}\right)$. (Emphasis added.)
} 
unable to conform to society's rules. It should be clear, even to the person who is relatively unsophisticated in the area of psychology, that unconscious forces are of considerable relevance in the motive patterns of some criminals, but of minor consequence in other cases. Strangely enough, however, a survey of the literature indicates that the seemingly obvious point must be made that not all criminals are alike. The rather peculiar thinking evidenced by some of the writers in the field of criminology, ${ }^{37}$ particularly those sociologists who follow Sutherland's "differential association" theory, seems to lead them to the erroneous assumption that because there exists a definable concept of "crime," "it" must have $a$ cause. Just a cursory consideration of the complexity of the concept itself, not to mention even a superficial acquaintance with the life histories of a few real criminals, should make abundantly clear that multiple causality is involved. To deny that multiple causality is involved in producing criminal behavior makes so little sense that it would seem that any approach to criminology that insists upon positing a single cause of crime would have little chance of being taken seriously. Yet, there seems to be a strong tendency for sociologists to attempt to formulate a single, comprehensive theory of the causation of criminal behavior, and thereby to deny or at least to depreciate the extreme relevance of individual differences in personality, particularly those differences that are related to unconscious processes.

While the "acting out" of unconscious conflicts is obviously not the cause of crime any more than is anything else, it unquestionably plays an important role in the causation of many illegal acts. Hence, if we wish to reduce crime by turning the individuals involved into persons who will be more apt to conform to the law's requirements, we must call upon the vast body of knowledge and techniques that psychiatry and clinical psychology have to offer. Unfortunately, truly definitive data regarding the efficacy of psychotherapeutic techniques used as a means of reducing recidivism are simply not available, but there are some extremely encouraging indications that significant results can be obtained, at least with some criminals. ${ }^{38}$ It must be emphasized, however, that

${ }^{37}$ See Cressey, The Differential Association Theory and Compulsive Crimes, $45 \mathrm{~J}$. CRIM. L., C. \& P.S. 29 (1954); Glaser, The Sociological Approach to Crime and Correction, 23 LAW \& ConTEMP. PROB. 683 (1958); Hartung, A Critique of the Sociological Approach to Crime and. Correction, 23 LAW \& CONTEMP. PROB. 703 (1958); Hartung, Methodological Assumption in a Social-Psychological Theory of Criminality, 45 J. CRIM. L., C. \& P.S. 652 (1954).

${ }^{83}$ See Ross, Some Implications and Results of the Psychiatric Treatment of Innates, 
it can be expected that psychotherapy will be effective only with some criminals. Character neurotics (individuals whose repressed conflicts are often resolved by "acting out" behavior that releases emotional tensions, the cause of which is not within their conscious perceptions) would be most benefited. Others, such as the senile psychotics, the psychopaths, or the young hoodlums raised in dyssocial, slum environments where the very essence of the social atmosphere involves criminal values, are not as likely to respond to psychotherapeutic efforts.

Much of the controversy over the desirability of implementing psychotherapeutic programs with convicted criminals hinges upon whether or not those who could be helped constitute a large enough proportion of the criminal population to make the effort worthwhile. This is an extremely important question, but unfortunately, one to which we can supply only the most tentative of answers. While a consensus of sorts could be obtained on the ineffectiveness of psychotherapy for deteriorated organics and perhaps also for dyssocial personalities (in whose case the major etiological factors seem often to involve the development of a relatively normal constellation of personality characteristics within a social environment laden with criminal values), there would be grave differences of opinion among psychiatrists over the effectiveness of therapy for psychopaths. This poses a problem, for some writers estimate that ninety per cent of the criminal population is psychopathic; however, others put the figure much lower; and still others deny both the meaningfulness of the concept and the existence of such a "type." There can be no question but that the term is a confusing one, nor that the diagnostic category has been used as a. "waste basket" for all kinds of odds and ends, with the result that there are several different "kinds" of psychopath, ${ }^{39}$ as well as varying intensities of psychopathic

I J. For. Scr. 117 (1956). At the time of publication of Ross's article, of 100 parolees treated in an outpatient clinic associated with the Medical Facility of the California Department of Corrections, only 5 had had their paroles suspended, and none of these had been convicted of having committed new crimes, after a year of operation of the clinic. The present writer's own experiences with prisoners at the California Medical Facility, and the demonstrable fact that the recidivism rate among parolees from the Medical Facility is less than half that of parolees from other prisons, cause him to feel that there are strong potentialities for the effective use of group and individual psychotherapy with a goodly proportion of convicted felons. It is too soon to be certain that the activities of the California Medical Facility represent anything other than a very effective selection system for choosing parolees, but the results obtained thus far are encouraging ratber than discouraging.

${ }^{30}$ See Dunaif \& Hoch, Pseudopsychopathic Schizophrenia, in Hocr \& ZUBIN, op. cit. 
disturbance. The degree to which it is believed possible to obtain therapeutic results with the psychopath is strictly a matter of opinion, and part of the difference in views results from this confusion over what actually constitutes a psychopath. The criteria utilized in defining the concept appear to range from those which accept any antisocial behavior as indicative of psychopathy to those based upon much more refined evaluations of the relationship of superego functions to total personality. The fact is that we just do not know very much about the various kinds of personalities that we have labeled psychopaths, and we are similarly in the dark about the extent to which psychotherapy can be of real use in preventing individuals so classified from committing further crimes.

However, in spite of the fact that we cannot describe precisely the personality syndromes that are represented in a prison population, it is still possible to make some generalizations about the characteristics that are in evidence. The extent to which the crimes committed by inmates can be clearly seen to have been motivated by irrational, often unconscious, factors is impressive. The real reasons for committing the crime are rarely those that the prisoner perceives to be relevant, and in many cases, uncovering psychotherapy is of great help in aiding the individual to understand his motives and thereby gain greater control over his behavior. Another surprising aspect is that so many of the prisoners are themselves aware of the irrationality of their own behavior, without being able to understand what their motivations really were. Many, of course, erect strong rationalizations and resist any suggestion that the sensibleness of their behavior can be questioned. Others, however, are quite upset by their perceptions of their own "unreasonableness."

A prisoner with a long and fairly "successful" criminal career once said, "By God, if anybody could tell me why I do what I do, I would be willing to be called insane and go to a state institution to be studied, or anywhere else.") In order to obtain psychotherapy, this "professional criminal"' gave himself up, knowing that he would receive an extra two years for parole violation. That he was unable to actually face his conflicts and received little help after entering a psychoanalytical

supra note $\mathrm{I} 7$, at 169 . The authors say that ' $(\mathrm{t})$ he term 'Psychopathic personality' has a phenomenological meaning which perhaps covers different etiological mechanisms. If one examines a number of people, conspicuous for their psychopathic behavior, three groupings will be found: (1) the classic psychopath; (2) the acting-out neurotic; (3) the acting-out schizophrenic." Id. at 169 .

${ }^{\circ}$ Alexander \& Healy, Roots of Crime 13 (1935). 
relationship points up the fact that psychotherapy is no panacea. But this particular criminal was well aware of the irrationality of his conduct and had a strong conscious desire to be helped in his efforts to control his behavior. The writer contends that a significant proportion of the prison population ${ }^{41}$ harbors similar desires (although they are seldom so dramatically expressed) and furthermore, that in enough of these cases to make its utilization a worthwhile endeavor, psychotherapy can be of invaluable aid by bringing about a reorganization of personality so that unconscious conflicts and impulses which have so greatly influenced behavior are brought under more conscious control and thereby lose their potency as motivating factors in the commission of antisocial acts. When it is understood that this, and not the production of "happy," psychologically well-adjusted individuals is the proper goal of psychotherapy with inmates, the implementation of an effective therapy program seems more feasible.

The criticism can easily be made that this contention is based primarily upon faith, for there are no carefully controlled experimental studies that demonstrate its truth. However, what meager systematic evidence we do have supports it rather than detracts from it, and the urgent need that exists for a more effective treatment of convicted criminals demands that we explore to the utmost any approach that

${ }^{41}$ It is necessary to differentiate between criminals and inmates of penal institutions. The latter counprise a more select group, for they are criminals who were canght. There are numerous variables that influence this selection process, such as intelligence, type of anti-social behavior indulged in, local attitudes, and laws, efficiency of the police force, chance factors, and so on, but a variable that must also be given due consideration is the amount of unconscious guilt harbored by the individual involved. It is not surprising to find that the proportion of character neurotics found among inmates is considerably higher than that estimated for the criminal population as a whole, for those who are motivated to commit crimes because they are unconsciously seeking punishment are exactly the ones who are most apt to be apprehended. Unless they "arrange things" so that they very likely will be caught, the real purpose of their act is lost. (The writer is aware that the contention that some criminals want to be caught and punished still seems extremely implausible to many people. What is truly farfetched, however, is the acceptance of any other explanation, once one obtains the full set of facts accompanying many seemingly ridiculous and obviously stupid crimes committed by intelligent individuals.)

Hence, there is undoubtedly considerable validity to the claim that guilt-ridden character neurotics (who are most likely to be helped by psychotherapy) are overrepresented in inmate populations. But since it is only the inmate population with whom it is possible to deal, the fact that there are probably far greater proportions of psychopaths and dyssocial personalities in the criminal population at large seems hardly relevant to any proposed plan for treating "criminals," since we can, after all, treat only inmates. 
holds promise of reducing the existing recidivism rate. If psychotherapy is completely impractical as a means of helping to deal with the problem of reforming inmates, time and systematic research will make this clear; but until such definite evidence is available, we should expand the use of psychotherapy as a means of effectively treating a significant proportion of our prison population.

It should be clear that this would not necessarily imply an abandonment of our basically punitive approach to dealing with criminals. The reformers who advocate such a complete change, indulging as they do in what Wechsler calls ". . . a kind of psychiatric crypto-ethics not uncommon in our culture, [holding that] anything that prefers commitment to conviction is desirable, ${ }^{342}$ overlook the very real deterring effect of punishment, especially the important influence threatened punishment has upon the great masses of individuals who are not criminals, but are always potentially so. To be effective, the criminal law must ascribe responsibility to all but the most obviously and extremely deviated, and it must contain sanctions involving some degree of punishment for unlawful acts. However, if we wish to do everything possible to prevent recidivism among convicted criminals, it is going to be necessary to utilize the knowledge and techniques made available to us by depth psychology and psychiatry. There can be little question but that until alterations in their personalities are made through the use of uncovering psychotherapy, many criminals can never "adhere to the right," no matter how much (nor how little) they are punished.

In order to clarify more fully the basis for the writer's contention that the basic punitive approach of the law must be retained, let us turn now to an appraisal of another suggestion that has frequently been forwarded as a means of improving the effectiveness of the criminal law; the suggestion that the sentencing function of the courts be placed in the hands of a group of psychiatric experts. Again, the advocacy of such an innovation is based upon a confusion of that which is more scientific in technique with that which is more effective for gaining a given end. It ignores the reality of the effects that such a change would produce in the attitudes held by the majority of people, for “... (t)he symbol of the wise and just father, punishing wrongdoers, probably adds to the stability of society and to the average individual's feeling of security." 33

\footnotetext{
"2 Wechsler, supra note 33 , at 375 .

${ }^{48}$ GuttMacher \& Weimofen, Psychiatry aNd the LAW 446 (I952).
} 
The idea of separating the "guilt-ascribing" function from the sentencing function and leaving only the former in the hands of the court is by no means new. Francis Wharton proposed the establishment of a "disposition tribunal" some eighty years ago, and the suggestion has been reiterated by numerous supporters, most of them psychiatrists or criminologists, with increasing frequency during recent years. One great advantage of such a plan, say its proponents, is that the matter over which psychiatry and the law have most fundamentally and vociferously clashed, the problem of determining legal insanity and irresponsibility, would become an irrelevancy. Under such an approach, the concept of legal insanity and the finding of "not guilty by reason of insanity" would be totally unnecessary, and the endless and seemingly fruitless combat over establishing acceptable criteria for them would cease. All that the judge and jury would need to concern themselves with would be establishing whether or not the accused did or did not commit the crime with which he is charged; the determination of what to do with him if found guilty would be made by a tribunal of experts qualified to evaluate psychiatric and sociological data, thereby making the most rational disposition of each case, regardless of the individual's "sanity." It is assumed that the various dispositions available would include hospitalization, probation, and the indeterminate incarceration of "incurables," as well as unconditional release, should that be deemed the most rational approach to preventing recidivism in any particular case. Under this approach, the concept of universal responsibility ${ }^{44}$

... is applicable if the concept is brought to a broader social therapeutic meaning, a liability to comprehensive treatment provided by law. In this frame of operation the unlawful act invokes a community sanction separate from the guilt-finding ritual and at once disposes of the futile exercise of calibrating responsibility to a chimerical scale of legal guilt. Universal responsibility lays open to the the law breaker, regardless of mental status, a liability to a rational clinical manipulation which has within its resources imprisonment, hospitahization, probation, psychotherapy, and so on. Such a procedure would eliminate the defense of insanity in the guilt-finding process, but not bar the introduction of scientific evidence into a separate procedure of disposition.

There are numerous specific objections raised to such a plan, probably the weakest of which is the assertion that the panel of experts would be

\footnotetext{
"Roche, Criminal Responsibility, in HocH \& ZuBIN, op. cit. supra note I7; at 107, 114.
} 
inept; that they would not always make the proper decision because psychiatry and psychology are not "exact" sciences. No doubt errors would occur under such a plan, but there is little doubt but that there could be a much more rational disposition of individual cases than occurs under the existing state of affairs, wherein judges with little or no understanding of either sociology or personality dynamics daily make decisions in which sentences are set or suspended and individuals are incarcerated or placed on probation on the basis of idiosyncratic and often quite ridiculous criteria.

The fear of too much power falling into the hands of psychiatrists is also often voiced. Plans for a disposition tribunal most often include the possibility for a completely indeterminate sentence, making it theoretically possible for an offender to be sentenced to life imprisonment for stealing a car, should the experts decide that his personality pattern was such that there existed little chance that he could be reformed. The objection is usually leveled not so much at the "injustice" of a given criminal being so treated as the granting of this amount of authority to a group of "experts" who can agree no better on basic questions of diagnosis than psychiatrists do.

The few attempts that have been made to put such an approach into practice in the United States have all run afoul of constitutional objections. At various times, Washington, Louisiana, and Mississippi have enacted laws under which the sentencing power has been delegated to a panel of experts. ${ }^{45}$ In each case, the law was repealed because it was held to violate "due process," the basic argument being that responsibility is an inherent part of guilt, and a jury cannot evaluate an accused's guilt without evaluating his responsibility as well; hence, it must be a jury that decides whether an accused is responsible or not. This means that it must be the jury that really makes gross disposition of his case, since the decision on the matter of responsibility determines whether the accused should be sent to a mental hospital or to prison.

There is some validity to all of these criticisms, but in the writer's opinion, none of them brings out the major shortcoming of the disposition tribunal, which is that such an approach would tend to reduce

\$5 Washington: REM. \& BAL. CODE $\$ 2259$ (1909), declared unconstitutional in State v. Strasburg, 60 Wash. 106, zio Pac. z020 (1910). Louisiana: LA. CoDE Crum. Proc. arts. 268-73 (x928), declared unconstitutional in State v. Lange, $168 \mathrm{La} .958,123$ So. 639 (1929). Mississippi: Miss. CODE ANN., $\$ \S 1327,1328$ (1930), declared unconstitutional in Sinclair v. State, $16 \times$ Miss. 142,132 So. 581 (1931). 
the deterring effect of the criminal law by breaking down the widelyheld concepts of personal responsibility and immutability of punishment for wrongdoing. It has been contended here that in our society, general acceptance of free will and personal responsibility for conduct is a necessity in order that we may live together in a civilized fashion. It has been further asserted that anticipation of punishment for wrongdoing has a definite deterring effect upon the vast majority of our citizens, in spite of the fact that it does not deter all of them from committing crimes. There does exist among us a widely and deeply-held belief that "justice" requires a law breaker to suffer, and that this has nothing whatsoever to do with pragmatic considerations. In other words, we tend to believe that the proper function of punishment is retributive rather than utilitarian, and to the extent that we have it demonstrated to us that the law is, in actuality, utilizing punishment in only a utilitarian fashion, to that extent our belief in "justice" and the meaningfulness of our concepts of free will and personal responsibility will be shaken. While it may be true that the scientific view of man upon which psychiatry is based provides ample evidence that these latter concepts are highly erroneous, they are no less a necessary part of our belief system if our society is to function effectively. To establish a disposition tribunal of the type described would, the writer fears, accomplish less good than harm; for while it could allow for a more rational treatment of convicted criminals, it would seriously challenge many beliefs that are of crucial importance for the effective functioning of the criminal law.

Were such an approach to be effected, the elimination of the insanity plea would imply that everyone was being held equally irresponsible; for to maintain that the law would be holding everyone equally responsible by considering them "liable to a rational clinical manipulation," as Roche puts it, is but one rather peculiar interpretation. A more probable one, as far as the general public is concerned, would be that all criminals were being considered equally irresponsible, in that, sane or insane, they would all be turned over to a group of psychiatric experts for treatment. Even if a disposition tribunal should decide that a particular criminal should be subjected to severe and prolonged punishment, this would still be perceived as a treatment that had been prescribed as a means of curing a sick individual, rather than a just retribution for a crime committed as a free act of evil intent. There is considerable difference in the effects produced upon the public when 
the functioning of the criminal law is perceived in the one way rather than the other. Guttmacher and Weihofen have asked: ${ }^{40}$

Fundamentally, why should it make any difference whether a person who has committed a criminal act was sane at the time and therefore guilty, or "not guilty by reason of insanity"? In either case he has shown himself a menace to society who must be taken into custody and control. Why worry over whether that control is based on criminality or insanity?

The basis of the answer to their questions would seem to be the fact that our concept of guilt has inherent in it the concept of responsibility for one's acts, and it is of importance to determine whether the individual in question was or was not a free moral agent capable of controlling his behavior; for however erroneous belief in this concept of free choice may be, it is a concept that must be retained if we are to be maximally influenced by moral and ethical considerations. To maintain that it makes no difference whether we incarcerate a man for a criminal act or commit him to an institution as a sick individual is to overlook the extremely important effects that such a straightforward utilitarian philosophy would have upon the population as a whole. Perhaps for the psychiatrist, “. . . the individual's social dangerousness and not his moral blameworthiness is the essential criterion in administering the criminal law, ${ }^{347}$ but this is by no means true for the majority of people. For them, the moral blameworthiness of the accused person is a factor of extreme relevance.

It is not necessary, however, to resort to the argument that the function of punishment should be conceived as retributive rather than utilitarian simply because that is the way in which the majority of people think of it, for there is another fallacy in the reasoning underlying the view that punishment should be utilized in a utilitarian way in order to be most effective. The avowed basis for this latter position is the assertion that in order to be effective, man must apply the same objective and scientific method to the study of himself that he has used in mastering the physical environment. Human behavior will then be conceived as a dependent variable, the form of which is determined solely by antecedent conditions. It is possible to concede this point and still deny the meaningfulness of an approach that maintains that there is no value in supporting the concept of personal responsibility, for such an ap-

\footnotetext{
${ }^{46}$ GuTTMACHER \& WeIHOFEN, op. cit. sipra note 43 , at 443 .

${ }^{47}$ Id. at 444.
} 
proach artificially excludes certain highly relevant antecedent conditions from their role as determining factors.

It is true, and properly so, that no one today would hold a tree "responsible" for being undersized and bearing inferior fruit. In order to deal most effectively with the problems involved in producing trees that manifest the characteristics we desire, we must maintain a completely objective attitude toward the trees; in fact, we must refrain from picturing them as moral agents at all. To blame a tree or praise it, or to blame hostile gods or demons for its performance, is irrelevant and childish behavior that is without effect, we have discovered, for the performance of the tree is completely determined by such antecedent conditions as the amount of fertilizer and water used, the presence or absence of noxious elements in the soil, etc. Since the tree can do nothing but respond to the physical influences that act upon it, we must concern ourselves only with these relevant determining influences if we wish to alter its performance.

Some of those who desire to see the scientific method brought to bear to help solve the problem of criminality have concluded that we must adopt the same attitude toward the criminal that we have adopted toward the tree-i.e., we must not ascribe blame to him, nor hold him responsible for his actions, but must recognize instead that he, like everything else in the universe, is merely responding to the influence of the forces which act upon him. If he behaves in a criminal manner, it is because he has been influenced by certain antecedent determining factors, and the proper endeavor is to attempt to undo their effects through a treatment approach, not to blame the individual for "behaving badly."

The fallacy in this argument is that this attitude toward criminal acts, if widely held in a society, could itself function as one of the relevant antecedent conditions tending to produce criminal behavior. Trees, gods, and demons are not sensitive to human praise or disapprobation; human beings are. In other words, blaming human beings for their acts is quite different from blaming trees, simply because a tree is so constructed that "blame" short of physical damage cannot have any stimulus function whatever, while the human organism, though equally subject to antecedent conditions as the sole determinants of its performance, is so constructed that the attitudes held toward it by members of its own species during its development constitute a type 
of relevant antecedent condition. To give official support to the idea that we are all equally responsible because no one is really responsible would be to produce a detrimental effect upon the behavior of a sig. nificant percentage of the population-individuals whose particular constellations of conflicts, values, and needs are such that they possess a predisposition toward antisocial acts, but are inhibited from committing them by a belief in their own personal responsibility for their actions and by their anticipation of justly meted punishment. That there exist some who are well-adjusted enough to remain unaffected to any significant degree by such a realistic appraisal of man may be true; that there are some whose personality patterns are such that they behave in a criminal manner in spite of the fact that they are aware that they will be held accountable is manifestly demonstrable. However, a large percentage of the population lies somewhere between these two extremes, and it is with this potentially antisocial element that we must be concerned if we are most significantly to appraise the effects of a shift toward a "treatment" approach to criminality.

There is still another not unrelated danger inherent in any plan to remove the ultimate criteria for social control from their roots in the beliefs and values of a given social group. Waelder states this problem succinctly when he says: ${ }^{48}$

[T] he complete elimination of the concept of retribution from the legal system may not be without danger. It would tend to dissociate the law entirely from moral sentiment. If the law no longer must conform, by and large, to moral standards, utilitarianism or expediency becomes its only guide. The emancipation from traditional moral sentiments, begun at first for humanitarian purposes, may eventually have consequences not so humanitarian. Once everything can be done that appears to be socially useful, i.e., that is so considered by those who have authority to define social usefulness, a course has been charted that may well end in despotism. Liberal positivism, in its humanitarian distaste for the harsher aspects of traditional morality, may, by undermining the authority of traditional morality, become the pathbreaker of more ruthless successors. The liumanitarian goal with which $\mathrm{I}$ am in full sympathy seems to me to be better served by the progressive mitigation of the severity of retribution rather than by an attempt to eliminate the retributive aspect altogether.

"s Waelder, Psychiatry and the Problem of Criminal Responsibility, 1ox U. PA. L. REV. 378,387 (1952). 
His last sentence suggests an important but infrequently appreciated differentiation that should be made. Such evidence as there is that shows that severe punishment is ineffective as a means of controlling the criminal behavior of some individuals might perhaps call for a reduction in the severity of punishment, but not the complete removal of the retributive aspect of the criminal law. To insist that mild punishment, carefully utilized, may accomplish as much as severe punishment may be a defensible position, but it is highly doubtful that the desired ends of the criminal law can be attained through the use of an approach from which the retributive (and hence the punitive) aspects have been eliminated. It is for this reason that the disposition tribunal must be rejected, even though it may very well be true that more rational dispositions of individual cases would be possible under such an approach.

Similar grounds exist for rejecting the Durham Rule. For the very reason that the Durham Rule is more rational and does allow for meaningful psychiatric testimony to be given, it must be rejected as a means for determining "insanity" and "irresponsibility." It allows for the direct introduction of psychiatric reality. into the courtroom, a state of affairs that is quite undesirable for the effective functioning of the criminal law. We must believe in personal responsibility and free will if the law is to function; all that is required of the law is that it allow us to be consistent with our beliefs by not punishing persons who are so extremely and obviously deranged that they are clearly not capable of exercising their free will. What is required is some specified criteria for establishing the degree of derangement that is to be considered obvious and extreme. The Durham Rule, rather than providing this, allows for testimony to be introduced that tends to break down our whole conceptualization by repeatedly pointing up the fact, if anyone cares to take its implications seriously, that no line of demarcation can really be drawn, and that everyone actually is equally irresponsible, regardless of the practical demands for responsible behavior that the psychiatrists may have agreed to accept among themselves.

Should we, then, retain the M'Naghten Rules, falling back upon the familiar rationalization that "no better criteria can be established"? This, too, seems an unacceptable alternative, in light of the severe and widespread dissatisfaction with them that exists. The basic cause of this discontent is that the M'Naghten Rules represent just a bit too irrational an approach to the problem of criminal irresponsibility, for 
they make it so obvious that reality is being distorted that we become uneasy. Fortunately, there exists a means of determining irresponsibility that appears rational enough to be respectable and at the same time, gives a legal definition to insanity, thereby preventing the undesirable introduction of psychiatric reality into the courtroom. The means referred to is the proposal of the American Law Institute contained in the Model Penal Code, a proposal seconded, as it were, by the New York Governor's Conference on the Defense of Insanity. According to this proposal: ${ }^{40}$

(I) A person is not responsible for criminal conduct if at the time of such conduct as a result of mental disease or defect he lacks substantial capacity, either to appreciate the criminality of his conduct or to conform his conduct to the requirements of law.

(2) The terms "mental disease or defect" dö not include an abnormality manifested only by repeated criminal or otherwise anti-social conduct.

Such a formulation is more realistic than the M'Naghten Rules, in that it does not limit the criteria to "knowledge" of right and wrong or the nature and quality of an act, but speaks of a "capacity" to appreciate the criminality of an act, or to do what is required by the law. Some of the major objections to the M'Naghten Rules-i.e., that they overemphasize the importance of cognitive functions, that they do not clarify what is meant by "wrongness," and that they do not allow for the existence of "irresistible impulses"-are thus met. That there exists a strong probability of future disagreement over the meaning of "capacity" and "substantial" cannot be denied, but this is beside the major point, which is that under the Model Penal Code, the determination of who is and who is not responsible is a function that would be left in the hands of the law. The interpretations given to the words "substantial capacity" might vary, but the common interpretations would contain an expression of the prevailing sentiments in the society, which would mean that none but the "obviously" mentally deviant individuals would be excused from responsibility. That this is the intention of the formulators of the Code would seem to be indicated by part (2), which is an obvious attempt to keep individuals who are not "crazy" (e.g., psychopaths) from escaping responsibility for their criminal acts. Thus, we have in the Model Penal Code an approach that will accomplish essentially what the M'Naghten Rules accomplish, the excusing from criminal

\footnotetext{
"Modfl Penal Code $\$$ 4.01 (Tent. Draft No. 4, 1955).
} 
responsibility of a small percentage of extremely deviant individuals whose condemnation and punishment would prove disturbing to us because they are manifestly not the same as the rest of us. The major difference is that the Model Penal Code appears to be more in harmony with current knowledge concerning cognition and conation and their relationships to overt behavior, thus satisfying our need for an approach that is not so anachronistic as that based upon the M'Naghten Rules.

The real value of the Model Penal Code's formulation, however, is that the acquiescence to the demands of psychiatric reality is limited to a merely semantic reformulation of the criteria to be utilized in establishing responsibility; it remains firmly based in the assumption that the vast majority of individuals are to be held responsible, while only the few who can be demonstrated to a jury's satisfaction to be lacking in "substantial capacity" will be held to be irresponsible. It is a jury of one's peers who will, ultimately, decide whether there is present the requisite "substantial capacity," thereby avoiding the real danger involved in taking the findings of psychiatry into serious considerationi.e., the danger of admitting the relevance of the mental abnormality that is present in a very large number of crimes and the absence of the capacity to have acted otherwise that is present in all crimes.

Returning, by way of conclusion, to the case presented at the beginning of this paper, it will be remembered that there appeared to have been an injustice committed in the attempt to utilize a nonpunitive approach within the existing framework of our legal system. It certainly cannot be denied that the inmate's sentence of one year to life in the state prison system must have seemed grossly unfair to him, but it should be clear that the judge's disposition was consistent with the position taken in this paper. The administration of the criminal law does involve more than merely making certain that the apprehended criminal will never again commit an illegal act. It is the inability of the advocates of a completely nonpunitive approach to realize this basic fact that creates so much of their misunderstanding of what the law must demand. From the standpoint of the inmate under consideration, being sent to prison after being "cured" was a great personal inconvenience, to put it mildly, and unjust because in so far as his particular needs were concerned, it was totally unnecessary and seemed to serve only the blind needs for revenge extant in the criminal law. But if the 
judge's decision was to be based upon a cognizance of the total function of the law, he had no choice but to deny probation. The law's deterring effect upon potential offenders (a function that definitely exists, despite the limited perception of many reformers) would have been diminished by releasing an offender from punitive action simply because he was no longer "sick." That the real effect of this single case would have been minute is beside the point.

Critics of the above position are frequently wont to distort an aspect of the situation. There is implicit in their arguments the assumption that by exposing to punitive action a man like the inmate we have considered, we will "undo" all of the good that has been done by psychotherapy. This is simply untrue. There can be no question but that differentiations can be made among prison environments as to the degree to which they are conducive to effective psychotherapy, but this does not mean that the consequences of a successful psychotherapy can be undone or prevented simply by placing the individual in a prison environment, provided that there is no extreme brutality or injustice in the treatment of the prisoners and that there is proper emphasis given to the function of psychiatric services. Being incarcerated may cause him to experience frustration, but if the psychotherapy has been successful, the inmate should have new means for coping with frustration. Indeed, incarceration may be considered a worthwhile test of an individual's capacity to deal with one kind of stress-producing situation. If certain requirements of organization and underlying philosophy are met, there is nothing at all inconsistent about utilizing psychotherapy in conjunction with reasonable punitive action, either in the way exemplifed by the case we have considered here or within the prison itself. Two different but equally necessary ends are being served by the two processes, and once this is understood, the seemingly paradoxical aspect involved in combining them is seen to be more apparent than real.

Unquestionably, there will occur under any such approach many instances in which individuals feel that they have been treated unfairly, but we can only be concerned with the extent to which this feeling is apt to increase the probability of recidivism, and not with the inmates' feelings per se. Unless there is adequate evidence that such resentment will undo whatever positive effects psychotherapy has had, there can be no real ground for concern, for the very simple reason that the crime problem has reached such proportions in the United States today that it has 
become mandatory that we express our major concern over that which is required for a more effectively functioning society, rather than that which works for the maximum personal satisfaction of individuals found guilty of committing crimes. Whenever a legal institution can function in such a manner that both values can be realized, it is all to the good, since punishment is not an end in itself. But when there exists a conflict between these two values, we must clearly understand that if we are really serious in our assertions that we desire to reduce the crime rate, we must accept the simple and seemingly obvious proposition that, in this area, the needs of society are of greater importance than the immediate needs of individuals who break the law.

\section{BIBLIOGRAPHY}

Alexander; Franz, \& Healy, William, Roots of Crime (i935).

Alexander, Franz, \& Staub, Hugo, The Criminal, the Judge, and The Public (I93I).

Arnold, Apologia for Jurisprudence, 44 YaLe L. J. 729 (I935).

Arnold, Thurman W., The Symbols of Government (i935).

Bensing, A Comparative Study of American Sex Statutes, 42 J. CRIM. L. \& CRIM. 57 (195I).

Bergan, The Sentencing Power in Criminal Cases, i3 Albany L. Rev. I (I949).

Berliner, Some Aspects of Mental Abnormality in Relation to Crime, $46 \mathrm{~J}$. CRIM. L., C. \& P.S. 67 (I955).

Bibb, Criminal Responsibility and Mental Disease: A Panel, 26 Tenn. L. REV. 22 I (1959).

Biggs, Procedures for Handling the Mentally-ill Offender in Some European Countries, 29 TEMPLE L. Q. 254 (I956).

Biggs, John Jr., The Gutlty Mind (I955).

Bromberg \& Cleckley, The Medico-legal Dilemma-A Suggested Solution, 42 J. CRIM. L., C. \& P.C. 729 (I952).

Cantor, Nathaniel F., Crime and Society (1939).

Cavanagh, The Responsibility of the Mentally Ill for Criminal Offenses, 4 CATHOLIC LAW. 317 (I958).

Cleckley, Hervey, The Mask of Sanity (1950).

Cressey, The Differential Association Theory and Compulsive Crimes, 45 J. CRIM. L., C. \& P.S. 29 (I954).

Cutler, Insanity as a Defense in Criminal Law, 5 Catholic Law. 44 (I959). 
Davidson, Irresistible Impulse and Criminal Responsibility, I J. For. ScI. I (I956).

de Grazia, The Distinction of Being Mad, 22 U. CHr. L. REv. 339 (1955). Dession, Justice After Conviction, 25 Conn. BAR J. 215 (I95I).

Donnelly, Establishment of Criminal Responsibility, 33 CoNN. BAR J. 137 (I959).

Friedrich, Carl J., The Philosophy of Law in Historical PerSPECTIVE (1958).

Frym, Past and Future Criminal Rehabilitation, 3 J. PuB. L. 45 I (I954).

Gasch, Prosecution Problems Under the Durham Rule, 5 CarHolic LAw. 5 (I959).

Gausewitz, Considerations Basic to a New Penal Code, I I WIs. L. Rev. 346,480 (1936).

Gibb, Diminished Responsibility for Crime, Scots Law Times, March 21, I 959, P. 85.

Glaser, The Sociological Approach to Crime and Correction, 23 LAw \& Contemp. Prob. 683 (1958).

Glueck, Changing Concepts in Forensic Psychiatry, 45 J. CRIM. L., C. \& P.S. 123 (I954).

Glueck, Pre-Sentence Examination of Offenders to Aid in Choosing a Method of Treatment, 4I J. CRIM. L. \& C. 7 I7 (I95I).

Glueck, Principles of a Rational Penal Code, 4 I Harv. L. REv. 453 (1928).

Grasset, Joseph, The Semi-Insane and the Semi-Responsible (i 907).

Guttmacher, The Psychiatric Approach to Crime and Correction, 23 LAw and Contemp. Prob. 633 (1958).

Guttmacher, The Psychiatrist as an Expert Witness, 22 U. CHI. L. REv. 325 (1955).

Guttmacher, Manfred S., \& Weihofen, Henry, Psychiatry and the LAW (1952).

Hakeem, $A$ Critique of the Psychiatric Approach to Crime and Correction, 23 Law and Contemp. Prob. 650 ( I 958).

Hall, Jerome, General Principles of Criminal. Law (1947).

Hall; Psychiatry and Criminal Responsibility, 65 YALE L. J. 761 (1956). Hall \& Menninger, Psychiatry and the Law-A Dual Review, 38 Iowa L. REv. 687 (I953).

Harno, Rationale of a Criminal Code, 85 U. PA. L. REv. 549 (I937).

Hartung, $A$ Critique of the Sociological Approach to Crime and Correction, 23 Law and Contemp. Prob. 703 (1958).

Hartung, Methodological Assumption in a Social-Psychological Theory of Criminality, 45 J. CRIM. L., C. \& P.C. 652 (1955). 
Hayden, The Psychopathic Personality: Treatment and Punishment Alternatives Under Current and Proposed Criminal Responsibility Criteria, 10 Rutgers L. Rev. 425 (1955).

Hill, The Psychological Realism of Thurman Arnold, 22 U. CHI. L. REv. 377 (1955).

Hoch, PaUl H. \& Zubin, Joseph (Eds.), Psychiatry and the Law I955.

Holmes-Laski Letters (Howe ed. 1953).

Hodges, Pumishment, I8 Phil. Phenomenol. Res. 209 (I957).

Karpman, Criminal Psychodynamics: A Platform, 47 J. CRIM. L., C. \& P.S. 8 (1956).

Karpman, On Reducing Tensions and Bridging Gaps Between Psychiatry and the Law, 48 J. CRIM. L., C. \& P.S. 164 (1957).

Katz, Law, Psychiatry, and Free Will, 22 U. CFx. L. REv. 397 (1955).

Katz, Psychoanalysis and Law, 5 U. CHI. L. S. Rec. I3 (1956).

Keedy, Criminal Responsibility of the Insane-A Reply to Professor Ballantine, I2 J. CRIM. L. \& C. I4 (I92I).

Keedy, Insanity and Criminal Responsibility, 30 HARv. L. Rev. 535 (1917).

Keedy, Irresistible Imprise as a Defense in Criminal Law, roo U. PA. L. REV. 956 (1952).

Keedy, Tests of Criminal Responsibility of the Insane, I J. CRIM. L. \& C. 394 (Igro).

Klaven, Insanity and the Criminal Law- $A$ Critique of Durham v. United States-Introduction, 22 U. CHI. L. REV. $3^{17}$ (I955).

Kreutzer, Re-examination of the Briggs Law, 39 B. U. L. REv. I88 (I959).

McGee, Defense Problems Under the Durham Rule, 5 Catholic LaW. 35 (1959).

Menninger, Medicolegal Proposals of the American Psychiatric Association, I 9 J. CRIM. L. \& CRIM. 367 (1928).

Michael, Psychiatry and the Criminal Law, 2 I A. B. A. J. 27 I (I935).

Model Penal Code $\S 4$.oI (Tent. Draft No. 4, r 955).

Mowrer, Freedom and Responsibility: A Psychological Analysis, $6 \mathrm{~J}$. LEGAL ED. 60 (1953).

Overholser, Psychiatry's Contributions to Criminal Law and Procedure, 12 OkLa. L. Rev. I3 (I959).

Overholser, The Briggs Law of Massachusetts: $A$ Review and an Appraisal, 25 J. CRIM. L., C. \& P.C. 859 (I 935).

Redmount, $A$ Pantoscopic View of Law and Psychology, Io J. LEgal Ed. 436 (1958).

Roche, Criminality and Mental Illness-Two Faces of the Same Coin, 22 U. Chr. L. REv. 320 (1955). 
Roche, Phillip Q., The Criminal Mind (1958).

Rood, Statutory Abolition of the Defense of Insanity in Criminal Cases, 9 Mich. L. Rev. 126 (I9Io).

Ross, Some Implications and Results of the Psychiatric Treatment of Inmates, I J. For. ScI. I I7 (1956).

Royal Commission on Capital Punishment, 1949-I953, Report, CMD. No. 8932 (1953).

Sellin, Correction in Historical Perspective, 23 Law \& Contemp. Prob. 585 (1958).

Silverstein, Psychology, Mental Illness, and the Law, 6o W. VA. L. Rev. 55 (1957).

Silverstein, Psychology, Mental Illness, and the Law, 6o W. VA. L. REv. 133 (1958).

Stephen, Sir James FitzJames, A History of the Criminal Law of ENGLAND (1883).

Szasz, Psychiatry, Ethics and the Criminal Law, 58 Colum. L. Rev. I83 (1958).

Taylor, Partial Insanity as Affecting the Degree of Crime-A Commentary on Fisher v. United States, 34 CalIF. L. REv. 625 (1946).

Tinnelly et. al., Mental Disease and Criminal Responsibility: A Symposium, 4 Catholic Law. 294 (I958).

Waelder, Psychiatry and the Problem of Criminal Responsibility, Ior U. PA. L. REv. 378 (1952).

Wechsler, The Criteria of Criminal Responsibility, 22 U. CHI. L. REv. 367 (I955).

Weihofen, Henry, Insanity as a Defense in Criminal Law (i933).

Weifofen, Henry, Mental Disorder as a Criminal Defense (i954).

Weihofen, The Flowering of New Hampshire, 22 U. CHI. L. REv. 356 (1955).

Weihofen, Henry, The URge to Punish (1956).

Weihofen \& Overholser, Mental Disorder Affecting the Degree of a Crime, 56 Y ALE L. J. 959 (1947).

Wertham, Book review of Gregory Zilboorg's The Psychology of the Criminal Act and Punishment (I954), 22 U. CHI. L. REv. 569 (I955).

Wertham, Psychoauthoritarianism and the Law, 22 U. CHI. L. REv. 336 (1955).

West, $A$ Psychological Theory of Law, in SAYre, PaUl (Ed.), INTERPREtations of Modern Legal Philosophies 767 (1947).

Wright, The Role of Psychiatry in the Establishment of Criminal Responsibility, 3 I Conn. B. J. 24 (I957).

Yellowlees, Guilty But Insane, I J. For. MEd. 2 I I (1954). 
Zilboorg, A Step Toward Enlightened Justice, 22 U. CHI. L. Rev. 33I (I955).

Zilboorg, Gregory, Mind, Medicine, and Man (1943).

Zilboorg, Misconceptions of Legal Insanity, 9 AM. J. ORTHOPsYch. 540 (I939). 